\title{
THE VALUE OF RIB BIOPSY IN THE STUDY OF MARROW DISORDERS
}

\author{
M. S. R. HUTT, P. SMITH, A. E. CLARK, AND J. L. PINNIGER \\ From St. Thomas's Hospital and.Medical School, London
}

(RECEIVED FOR PUBLICATION FEBRUARY 7, 1952)

Specimens of marrow for histological examination may be obtained either by sectioning the particles present in a marrow aspirate or by surgical trephine of the sternum (Custer, 1933; Dameshek, Henstell, and Valentine, 1937; White, Baker, and Griffin, 1946). The former procedure is limited in many cases by the size of the particles withdrawn, while the latter, not infrequently, yields specimens consisting largely of bone and the marrow obtained may be distorted or too small for adequate histological study.

In view of these disadvantages it was decided to use rib biopsy as an alternative method for obtaining marrow for diagnostic purposes. The evaluation of normal variations and the selection and refinement of histological techniques were first undertaken on samples obtained at routine thoracotomies and at necropsy. Our findings are reported below.

\section{Surgical Technique}

The object of bone marrow biopsy is to produce a piece of bone with the medullary cavity undisturbed. This is most easily obtained, by one experienced in the technique, by resecting a small segment of rib subperiosteally. Although every patient was investigated before operation to exclude the probability of their bleeding excessively, this feature was not regarded as an absolute contraindication to the operation. In our series two cases showed haematomata at the site of operation, but these soon resolved with conservative treatment.

Of our 10 cases submitted to the procedure for diagnostic purposes, the first three were given local anaesthesia and the remainder general. The reason for the change-over was that it was more comfortable for the patient and was also a safeguard against accidentally opening the pleura. The operation is carried out in the theatre with full surgical asepsis and usually lasts about a quarter of an hour. A portion of rib $\frac{1}{2}$ to $1 \mathrm{in}$. long is removed from the midaxillary line according to the usual technique for subperiosteal resection. Haemostasis is simple and post-operative pain minimal.

\section{Histological Technique}

On receipt of the unfixed specimen smears are made from the marrow at one end of the rib either by direct impression or from particles removed with the point of a scalpel. These are dried in air, and fixed and stained with Leishman's stain as for ordinary marrow aspiration films.

The rib is then fixed for approximately 24 hours in $10 \%$ formalin neutralized with excess calcium carbonate, after which it is frozen with carbon dioxide snow. When frozen solid the rib is cut with a fine-tooth saw in the plane of its long axis and the greater diameter of its cut surface. Freezing before cutting ensures that the marrow is not torn away from the surrounding bone. This is particularly important if there is bony resorption secondary to marrow hyperplasia, when splintering is otherwise liable to occur.

The bisected rib is next decalcified with $5 \%$ nitric acid for four to eight hours. The usual procedure of neutralization with sodium sulphite is not carried out because we have found that the marrow cells show less shrinkage, and that the staining reactions, especially that with Leishman's stain, are much improved. The tissue is washed in running water for 24 hours, after which it is impregnated with and imbedded in paraffin wax in the usual way. Sections are cut at $4-5 \mu$ and are attached to slides by using a gelatin technique, i.e., the sections are floated on to hot water to which has been added gelatin to make a $0.5 \%$ solution. They are withdrawn on to clean slides and then dried in the incubator in formalin vapour. This stage is necessary, particularly when haematoxylin and van Gieson and reticulin methods are to be used, as otherwise the sections will come off the slides.

The slides are stained with Ehrlich's acid alum haematoxylin and eosin, Weigert's iron haematoxylin, and Van Gieson's stain, with Leishman's stain, and for reticulin. The first two staining methods are standard ones and need not be discussed. The Leishman's stain is a modification developed by one of us (Clark, 1952) and has yielded results-strikingly more satisfactory than any other method of which we have had experience.

The reticulin preparations have proved to be of great value in the study of the part played by connective tissue fibrils in haemopoietic disorders, and have given 


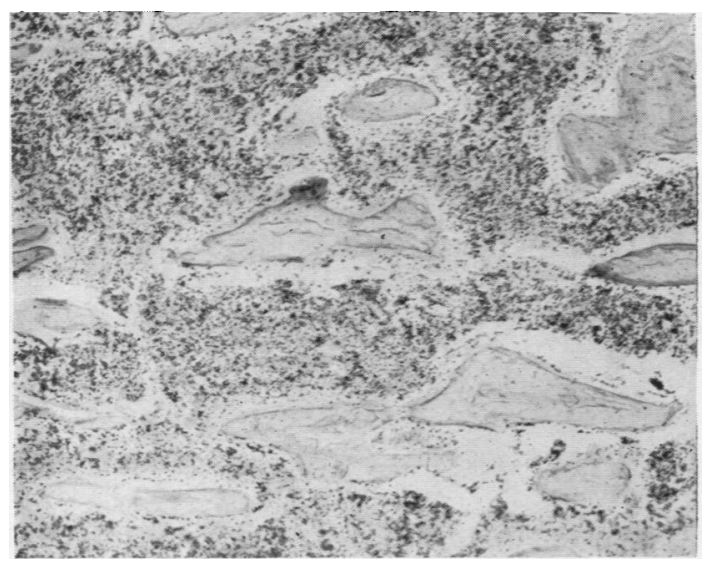

FIG. 1.-Norma! rib from an infant showing numerous bone trabeculae and absence of fat spaces in marrow tissue. Haematoxylin and eosin, $\times 42$.

diagnostic information in cases in which the van Gieson preparation was disappointing.

\section{Results}

Normal Series.-A series of 50 ribs obtained from necropsies and during thoracotomies has been examined. All were treated according to the techniques described. It was found that suitable marrow specimens were obtained in all cases, though the earlier fixation that was possible in the surgical cases led to their having better cellular detail than those taken at necropsy.

In order to relate the changes in marrow content to age, specimens were examined from foetal life upwards to the age of 80 . A rough estimate of. marrow cellularity was obtained by counting the number of fat spaces in a random selection of six fields using the $\times 40$ objective and $\times 6$ eyepiece.

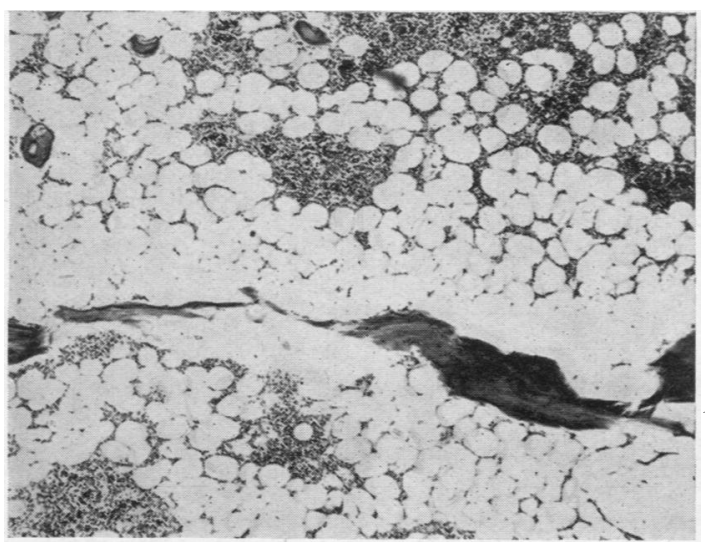

FIG. 3.-This section (Case 4) demonstrates the variation in cellularity that can occur. The islands are of normal haemopoietic tissue. Haematoxylin and eosin, $\times 42$.

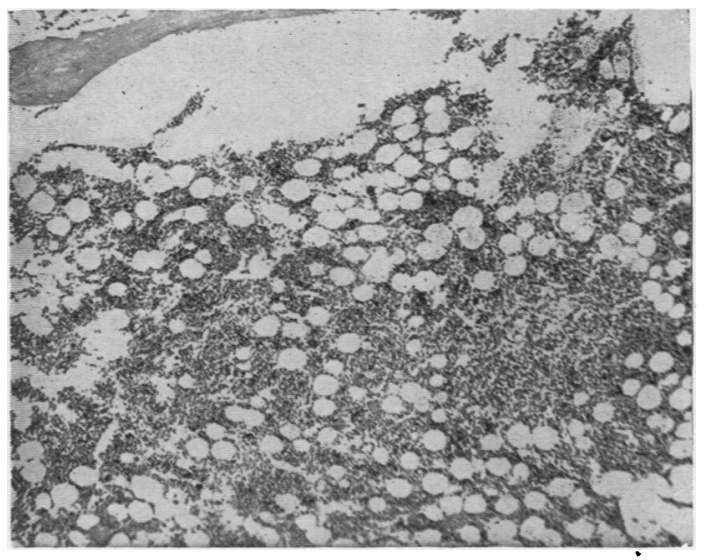

FIG. 2.-Rib from 20-year-old male showing haemopoietic tissue and fat spaces in normal proportions. Haematoxylin and eosin, $\times 42$.

In the two infants whose marrow was examined no such fat spaces were visible (Fig. 1); a few were present in a child of 4 and an average of 14 per field were seen in a boy of 12 . There was not much variation from this figure after this age, even in the old-age group, and in these preparations haemopoietic tissue was always abundant and was similar to that in other sites (Fig. 2). This indicated that the rib was suitable for the study of bone marrow from patients of any age, confirming Reich's conclusions in the case of sternal marrow (Reich, Swirsky, and Smith, 1944).

Diagnostic Biopsy Cases. - The details of the 10 cases in which rib biopsy was undertaken for diagnostic purposes are given in the Table. In some of these the biopsy was undertaken because marrow punctures had yielded dry taps or dilute

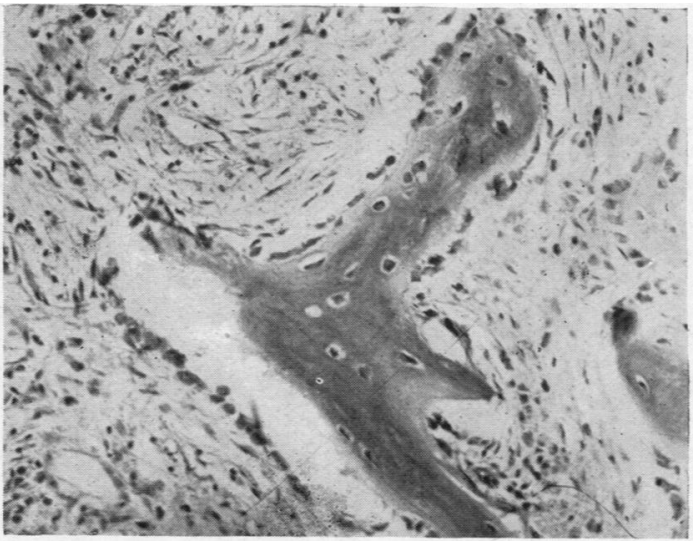

Fig. 4.-Marrow from Case 2 showing fibrosis with new bone formation. Haematoxylin and eosin, $\times 120$. 


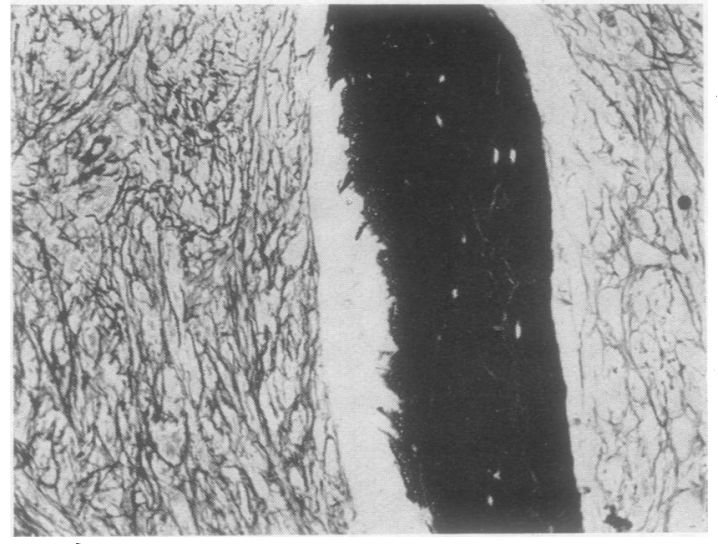

Fig. 5.-The same section as for Fig. 4. The fibrils are strikingly brought out by the reticulin stain. Van Gieson's stain was by contrast disappointing. Reticulin, $\times 120$.

specimens. On these occasions the biopsy specimen usually yielded diagnostic information, e.g., the presence of myelofibrosis in Case 1, of reticulum cell sarcoma in Case 3, and of secondary carcinoma in Case 6 (Fig. 6). Case 2 (Figs. 4 and 5) is an example of those leukaemic states which may be associated with an unsatisfactory marrow aspirate (Dacie and White, 1949). This case also illustrates the value of reticulin preparations in demonstrating the dense fibrillary nature of the connective tissue, a feature not apparent in the haematoxylin and van Gieson sections. Case 4 (Fig. 3) shows. how false impressions of the marrow structure can at times be gained by relying on aspiration alone. Cases 2 and 10 (Figs. 7 and 8) give an indication of the value of marrow biopsy in the study of the evolution of interesting marrow disorders.

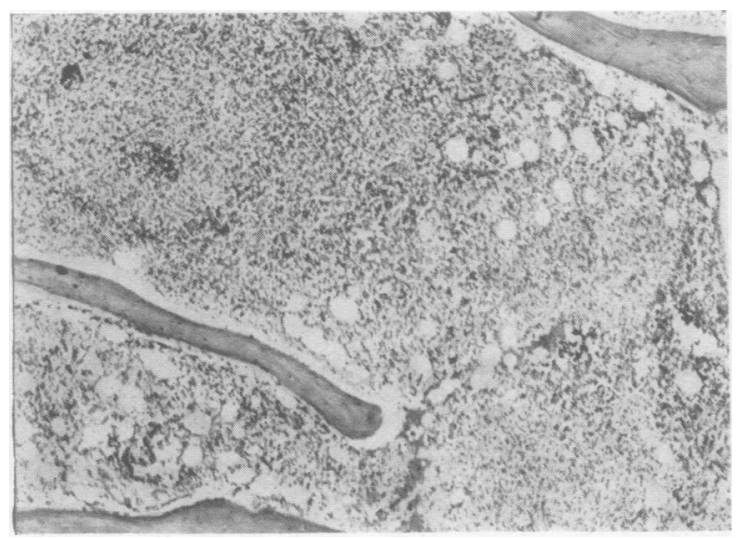

Fig. 7.-Marrow (Case 10) showing three rather ill-defined lymphoid follicles. Haematoxylin and eosin, $\times 42$.

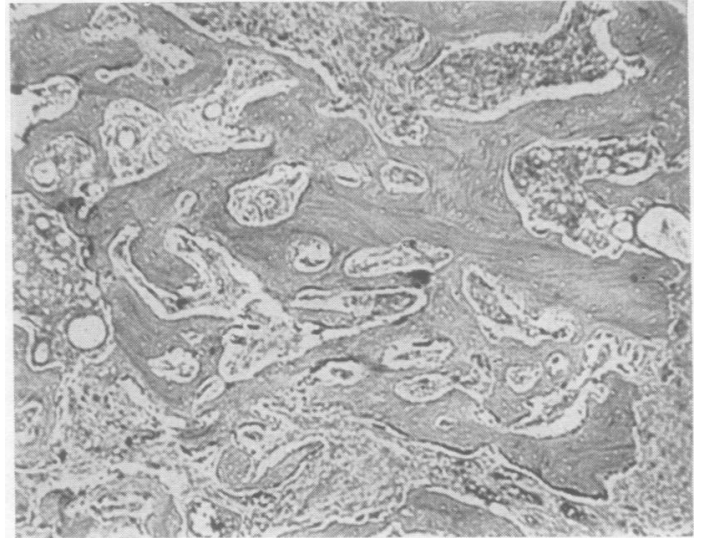

Fig. 6.-Secondary adenocarcinoma in bone marrow from Case 6. Active bone formation is well demonstrated. Haematoxylin and eosin, $\times 42$.

In Cases 5, 8, and 9 the biopsies were performed in order to obtain a clearer impression of the nature of the disorder and so come to a more confident diagnosis. In view of the fact that there were no serious post-operative complications we believe that rib biopsy is a useful additional tool in the comprehensive study of obscure haematological disorders, as it yields better histological preparations than any other method.

\section{Conclusions and Summary}

Our experience with rib biopsy leads us to the firm conclusion that it is in every way a more satisfactory procedure than sternal trephine in the study of the more obscure haematological disorders. While general anaesthesia is not imperative it is to be recommended. The operation, by one skilled in the technique, is easily performed, short, and

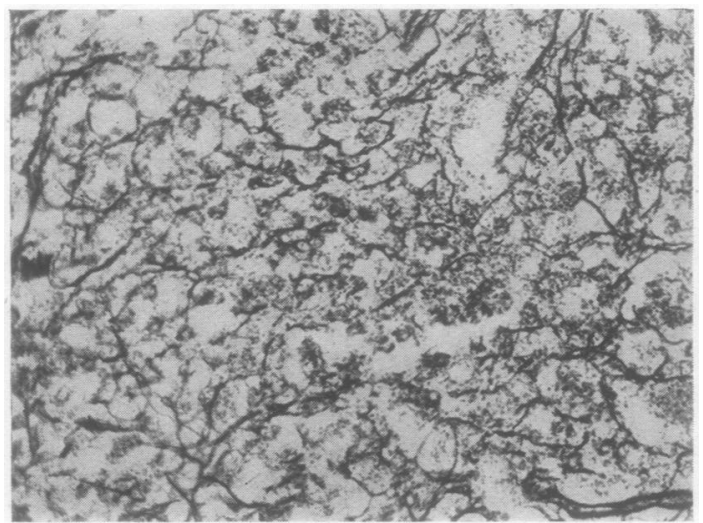

FIG. 8.-Marrow from Case 10 showing increase in number of reticulin fibrils. Reticulin, $\times \mathbf{2 4 0}$. 
TABLE

Summaries OF RiB BIOPSY CASES

\begin{tabular}{|c|c|c|c|c|}
\hline Case No. & Presenting Features & Marrow Puncture & Marrow Biopsy & Comments \\
\hline 1 & $\begin{array}{l}\text { Woman aged } 74 . \quad \text { Spleno- } \\
\text { megaly. } \\
\text { blastic anaemiaco-erythro- }\end{array}$ & $\begin{array}{l}\text { Aspiration difficult. Marrow } \\
\text { with normal differential } \\
\text { count }\end{array}$ & $\begin{array}{l}\text { Marrow fibrosis. Haemo- } \\
\text { poietic tissue present }\end{array}$ & \\
\hline 2 & $\begin{array}{l}\text { Man aged 53. Pancytopenia } \\
\text { with atypical " blast " cells } \\
\text { in peripheral blood }\end{array}$ & $\begin{array}{l}\text { Marrow felt " hard." Scanty } \\
\text { aspirate. having differential } \\
\text { count similar to peripheral } \\
\text { blood }\end{array}$ & $\begin{array}{l}\text { Extensive marrow fibrosis } \\
\text { with little haemopoietic } \\
\text { tissue and scattered atypical } \\
\text { primitive cells. (Figs. } 4 \text { and } \\
5 \text { ) }\end{array}$ & $\begin{array}{l}\text { Studies indicated a complex } \\
\text { state showing features of a } \\
\text { primitive cell leukaemia and } \\
\text { reticulum cell sarcoma }\end{array}$ \\
\hline 3 & $\begin{array}{l}\text { Man aged } 29 . \text { Generalized } \\
\text { lymphadenopathy. Neutro- } \\
\text { penia (Hb } 100 \%)\end{array}$ & $\begin{array}{l}\text { Dilute marrow obtained with } \\
\text { difficulty. Normal differen- } \\
\text { tial count }\end{array}$ & $\begin{array}{l}\text { Normal marrow pattern des- } \\
\text { troyed. Increase in collagen } \\
\text { and reticulin with reticulum } \\
\text { cells and fibroblasts scat- } \\
\text { tered through haemopoietic } \\
\text { tissue }\end{array}$ & $\begin{array}{l}\text { Gland biopsy revealed reti- } \\
\text { culum cell sarcoma }\end{array}$ \\
\hline 4 & $\begin{array}{l}\text { Man aged 60. Mass in left } \\
\text { loin? spleen. No significant } \\
\text { blood abnormalities }\end{array}$ & $\begin{array}{l}\text { Marrow aspirate relatively } \\
\text { acellular but otherwise } \\
\text { normal }\end{array}$ & $\begin{array}{l}\text { Section showed a fatty marrow } \\
\text { in which foci of active } \\
\text { haemopoiesis were present } \\
\text { (Fig. 3) }\end{array}$ & $\begin{array}{l}\text { Laparotomy revealed a renal } \\
\text { tumour }\end{array}$ \\
\hline 5 & $\begin{array}{l}\text { Man aged } 62 \text {. Refractory } \\
\text { anaemia with leucopenia } \\
\text { and splenomegaly }\end{array}$ & $\begin{array}{l}\text { Marrow cellular. Showed } \\
\text { normoblastic hyperplasia } \\
\text { with an increase of imma- } \\
\text { ture forms and an occa- } \\
\text { sional megaloblast }\end{array}$ & $\begin{array}{l}\text { Active somewhat immature } \\
\text { haemopoietic tissue with } \\
\text { absence of fat spaces. No } \\
\text { increase of fibrous tissue }\end{array}$ & $\begin{array}{l}\text { Biopsy to assist in assessing } \\
\text { advisability of splenectomy }\end{array}$ \\
\hline 6 & $\begin{array}{l}\text { Man aged } 55 \text {. Malaise and } \\
\text { loss of weight. Leuco- } \\
\text { erythroblastic anaemia }\end{array}$ & Dry tap & $\begin{array}{l}\text { Intense osteosclerosis due to } \\
\text { secondary mucus-secreting } \\
\text { carcinoma (Fig. 6) }\end{array}$ & \\
\hline 7 & $\begin{array}{l}\text { Woman aged } 64 \text {. Long his- } \\
\text { tory of anaemia and leuco- } \\
\text { penia. Splenomegaly }\end{array}$ & $\begin{array}{l}\text { Puncture twice performed } \\
\text { yielded dilute marrow of } \\
\text { normal differential count }\end{array}$ & Normal marrow & $\begin{array}{l}\text { Rib biopsy was done at the } \\
\text { same time as a liver biopsy. } \\
\text { The latter showed multi- } \\
\text { lobular cirrhosis }\end{array}$ \\
\hline 8 & $\begin{array}{l}\text { Man aged 63. Anaemia with } \\
\text { slight leucocytosis. Occa- } \\
\text { sional immature cell in } \\
\text { peripheral blood. Diag- } \\
\text { nosed elsewhere as mega- } \\
\text { karyocytic myelosis }\end{array}$ & $\begin{array}{l}\text { Marrow easily obtained. Dif- } \\
\text { ferential count was of } \\
\text { normal proportions. No } \\
\text { megakaryocytic hyperplasia } \\
\text { evident }\end{array}$ & $\begin{array}{l}\text { Hyperplastic marrow with } \\
\text { absence of fat spaces. Large } \\
\text { numbers of myeloid cells } \\
\text { and a great increase in the } \\
\text { number of megakaryocytes }\end{array}$ & $\begin{array}{l}\text { Marrow biopsy led to diag- } \\
\text { nosis of myeloid leukaemia } \\
\text { with associated megakaryo- } \\
\text { cytichyperplasia }\end{array}$ \\
\hline 9 & $\begin{array}{l}\text { Woman aged } 63 \text {. Spleno- } \\
\text { megaly with leucocytosis for } \\
\text { three years. No anaemia. } \\
\text { Occasional metamyelocyte } \\
\text { in peripheral blood }\end{array}$ & $\begin{array}{l}\text { Cellular marrow with myeloid } \\
\text { hyperplasia }\end{array}$ & $\begin{array}{l}\text { Marrow hyperplasia with } \\
\text { absence of fat spaces. Mye- } \\
\text { loid leukaemia. No increase } \\
\text { of fibrous tissue }\end{array}$ & $\begin{array}{l}\text { Sternal puncture and rib } \\
\text { biopsy were done at the same } \\
\text { time under anaesthesia. The } \\
\text { section showed a larger } \\
\text { number of primitive cells } \\
\text { than did the aspirate }\end{array}$ \\
\hline 10 & $\begin{array}{l}\text { Man aged } 71 \text {. Splenomegaly. } \\
\text { Anaemia and neutropenia. } \\
\text { Occasional immature cell in } \\
\text { peripheral blood }\end{array}$ & $\begin{array}{l}\text { Marrow easily withdrawn, but } \\
\text { dilute. The differential } \\
\text { count was of normal pro- } \\
\text { portions }\end{array}$ & $\begin{array}{l}\text { The marrow showed an in- } \\
\text { creased cellularity, the prin- } \\
\text { cipal abnormality being a } \\
\text { proliferation of reticulum } \\
\text { cells. An unusual number } \\
\text { of lymphoid follicles were } \\
\text { present. There was a definite } \\
\text { increase in the number of } \\
\text { reticulin fibrils (Figs. } 7 \text { and } \\
\text { 8). }\end{array}$ & $\begin{array}{l}\text { As a result of marrow biopsy } \\
\text { the case appeared to be one } \\
\text { of early myelofibrosis }\end{array}$ \\
\hline
\end{tabular}

unlikely to be attended by any serious complications. The specimens obtained can be prepared without difficulty to give first-class marrow sections. In the staining of the latter, the orthodox haematoxylin and eosin and van Gieson stains and an improved Leishman technique are recommended. The particular value of silver methods for connective tissue fibrils is also stressed. The 10 cases in which biopsy was performed are tabulated and discussed. The use of the procedure as a tool in the comprehensive study of haematological disorders is to be recommended in addition to its undoubted value in diagnosis.

The expenses of this study have been defrayed in part by the Endowment Fund, St. Thomas's Hospital.

\section{REFERENCES}

Clark, A. E. (1952). J. Path. Bact., 64, 423

Custer, R. P. (1933). Amer. J. med. Sci., 185, 617.

Custer, R. P. (193). Amer. (1949). Journal of Clinical Pathology, $2,1$.

Dacie,J. V., and White, J. C. (1949). Journal of Clinical Pathology, 2, 1. Dameshek, W., Henstell,

Reich, C., Swirsky, M., and Smith, D. (1944). J. Lab. clin. Med.,

$29,508$.
White, J. C., Baker, J. R., and Griffin, J. G. (1946). J. Path. Bact., 58,155 . 